\title{
Comparison of Clinical, Histological and Molecular Features of Primary Operable Breast Cancer in Patients from Kosovar and Croatian University Hospitals
}

\section{Faton Sermaxhaj}

University Clinical Centre of Kosovo: Qendra Klinike Universitare e Kosoves https://orcid.org/00000002-5856-535X

Natalija Dedić Plavetić ( $\square$ natalijadedicplavetic@gmail.com )

University Hospital Center of Zagreb https://orcid.org/0000-0003-0505-4756

Ana Kulić

University Hospital Centre Zagreb: Klinicki Bolnicki Centar Zagreb

\section{Ugur Gozalan}

Royal Medical Hospital Kosovo

\section{Ljubica Radmilović Varga}

Varazdin General Hospital: Opca Bolnica Varazdin

\section{Marina Popović}

University Hospital Centre Zagreb: Klinicki Bolnicki Centar Zagreb

\section{Slavica Sović}

University of Zagreb School of Medicine: Sveuciliste u Zagrebu Medicinski fakultet

\section{Davor Mijatović}

University Hospital Centre Zagreb: Klinicki Bolnicki Centar Zagreb

Fisnik Kurshumliu

University Clinical Centre of Kosovo: Qendra Klinike Universitare e Kosoves

Elton Bahtiri

University of Prishtina Faculty of Medical Sciences: Universiteti i Prishtines Fakulteti i Mjekesise

Besim Sermaxhaj

University Clinical Centre of Kosovo: Qendra Klinike Universitare e Kosoves

\section{Research}

Keywords: breast cancer, Croatia, Kosovo, mammography screening, stage.

Posted Date: February 5th, 2021 
DOI: https://doi.org/10.21203/rs.3.rs-165226/v1

License: (c) (1) This work is licensed under a Creative Commons Attribution 4.0 International License. Read Full License 


\section{Abstract \\ Background}

The aim of this study was to explore the clinical, patohistological and molecular characteristics of primary operable breast cancer in patients from Croatia and Kosovo, in order to compare disease stage at the time of diagnosis, in country with implemented mammography screening and early diagnostic methods with country without it.

\section{Methods}

The study prospectively included 213 female patients with breast cancer (BC) ranging from 28 to 87 years of age, from which 100 from Kosovo and 113 from Croatia. Age and menopausal status of the patients were recorded before surgery. Subsequent to surgery, histopathology and immunohistochemistry analysis was carried out and data were statistically analysed. Categorical variables were compared using chi-square analysis and presented as frequencies and percentages. For non-parametric data, MannWhitney $U$ test was used in order to compare means of two independent groups. A value of $P<0.05$ was considered statistically significant.

\section{Results}

There were larger tumors, more patients with metastatic axillary lymph nodes and more stage III patients in Kosovo cohort. In addition, the rate of lympho-vascular invasion (LVI) and the expression of progesteron receptor (PR) were significantly higher in Kosovar patients. The other histological and immunohistochemical features were not found to be any different in the two cohorts.

\section{Conclusions}

The results of this study from two university hospitals from Croatia and Kosovo demonstrate that the BC patients in Kosovo have more advanced stage of disease at the time of diagnosis compared to Croatia.

\section{Background}

As in Europe, $\mathrm{BC}$ is the most common malignant tumor among women in Croatia, with a quarter of the newly diagnosed women with cancer, having BC [1]. In 2016, among Croatian woman, 2735 new cases of BC were registered (126.6 per 100,000 people) with 990 death cases ( 45.8 per 100,000 people), making it the most common cause of death for women diagnosed with cancer in Croatia [1]. A constant increase of the incidence of BC is evident, with 2303 cases of women in 2005 and 2748 cases of women in 2015. However, with the stabilization of the mortality trend in recent years, the number of cases in 2012 was 1033, whereas in 2016 dropped to 990 cases [1, 2, 3, 4]. Compared to other European countries, Croatia 
has medium-high incidence and high mortality from BC. Some progress has been made in the last 15 years regarding the treatment of $\mathrm{BC}$ and cancer survival rates in Croatia; however, the progress is still below the European average.

Since 2006, when the National Program of Breast Cancer Early Detection (Mamma) was first carried out in Croatia, the share of newly diagnosed BC in the localized stage among women (50-69 years old) is $60-70 \%$, whereas prior to the start of Mamma, it was $40 \%$. The positive effect of the implementation of the screening program of $B C$ is also evident in the 2017 data, showing a $15-20 \%$ reduction in the mortality rate from $\mathrm{BC}$. A significant achievement has been seen in the last two years: there was a decrease in mortality from $\mathrm{BC}$ in all age groups, with the largest decline in the older age groups, 70 years and above.

According to the results of CONCORD-3 study, which analyzed individual records of 37.5 million patients diagnosed with one of 18 cancers from 322 population-based registries in 71 countries, Croatia is in the lower half of the European rankings for BC 5-year survival (79\%) [5]. In comparison, according to EUROCARE-5 study, 5-year BC survival for women diagnosed between 2000 and 2007 in Croatia was $76.3 \%$, while the average of European countries was $81.8 \%$ [6]. According to aforementioned data, over the last 15 years there has been progress in terms of cancer survival in Croatia however, there is still room for improvement.

In contrast, data in relation to situation with $\mathrm{BC}$ in Kosovo are limited. The data from the Kosovo Agency of Statistics-health statistics, shows a steady increase of new BC cases by each subsequent year. During the period of 2012 to 2018 there has been a continuous increase in the number of new cases ranging from 207, in the year 2012 to 444 new cases in the year 2018[7]. Notably, in 2019 there were 376 new registered cases (20.9 per 100000 people). These figures in Kosovo can be attributed to the worldwide increase of incidence as well as improved reporting, better means of detection and diagnosis and the increased awareness of the population. In addition, the implementation of the mobile mammography program, established in 2014, has played a role in terms of the reach out of patients living in remote areas. According to the Kosovar data, only about $40-50 \%$ of cases are diagnosed in the early stages of the disease, regardless of age. However, data on survival and mortality rates of $\mathrm{BC}$ patients in Kosovo are not available.

The aim of this study was to evaluate clinical and histological characteristics of patients' cohorts who underwent primary surgical treatment due to BC in two university hospitals, one in Zagreb, Croatia and the other in Prishtina, Kosovo in order to compare disease stage at the time of diagnosis, in country with implemented mammografical screening with country without it.

\section{Methods}

This cross-sectional, observational and analytical study included female patients with BC who underwent surgery in University Hospital Center of Zagreb, Croatia and in University Hospital Center of Kosovo in Prishtina, from Januar 2018 till June 2019. They were treated by partial mastectomy with axillary lymph 
node dissection or modified radical mastectomy as their primary treatment, and afterwards assigned to receive adjuvant chemotherapy, endocrine therapy and adjuvant radiotherapy as indicated by tumor biology and disease stage according to guidelines valid at the time [8]. The study included 100 patients from Kosovo and 113 from Croatia. The study excluded patients with omitted axillary dissection, patients with R1 or R2 resection, non-invasive carcinoma in situ (DCIS), patients with lack of histopathology reports and/or immunohistochemistry results, patients with other malignant diseases, patients who had underwent neoadjuvant chemotherapy or endocrine therapy, patients with stage IV disease or those with dementia or psychiatric disorders being unable to willingly participate in the study. Age and menopausal status of the patients were recorded before surgery. Subsequently, histopathological and immunohistochemistry data were collected. Tumor size, histological type, histological grade according to Nottingham, presence or absence of LVI, number of positive lymph nodes and resulting stage of disease were noted. Also, data on molecular markers such as: immunohistochemical expression of estrogen receptor (ER), PR, amplification of Her-2/neu receptor and proliferation index as measured by Ki-67 were obtained. Tumor staging was based on the 8th American Joint Committee on Cancer System (AJCC) [9]. Histological subtyping has been determined according to the World Health Organization Classification criteria [10]. ER, PR, Her-2 status and Ki-67 proliferation index were interpreted according to the criteria by American Society of Clinical Oncology (ASCO), and St. Gallen International Expert Consensus [8, 11]. According to these recommendations, ER and PR are considered positive if $\geq 1 \%$ of tumor cell nuclei exhibit positive reaction. According to the same criteria Her-2/neu expression by immunohistochemistry may range from 0 to 3 . If the result is 0 to 1 it is considered negative. In contrast, if the result is 3 it is considered positive. Cases with the value of 2 are considered equivocal and are rendered for Fluorescent in situ hybridization (FISH) or Chromogenic in situ hybridization (CISH) analysis. Based on the St. Gallen International Expert Consensus criteria, the value of Ki-67 less than $20 \%$ is considered low, and values of Ki-67 above or equal to $20 \%$ are considered as high proliferation index in order to discriminate between luminal A and luminal B surrogate subtypes [8]. The St. Gallen Consensus recognizes five molecular surrogate subtypes of invasive $B C$ according to the expression of formerly mentioned molecular markers namely, Luminal A-like, Luminal B/Her-2 negative-like, Luminal B/Her-2 positive-like, Her-2 positive type and Triple negative, (Table 1).

Table 1

Molecular surrogate subtypes of invasive breast cancer according to St Gallen Consensus.

\begin{tabular}{|lllll|}
\hline Subtype & & ER and/or PgR & HER-2 & Ki-67 \\
\hline Luminal A-like & (LumA $)$ & Positive, $\geq 20$ & Negative & $<20$ \\
\hline Luminal B/HER2 negative-like & (LumB/HER2 neg.) & Positive, $<20$ & Negative & $\geq 20$ \\
\hline Luminal B/HER2 positive-like & (LumB/HER2 pos.) & Positive & Positive & Any \\
\hline HER-2 positive & Her-2 overexpression & Both $(-)$ & Positive & Any \\
\hline Triple negative & $(\mathrm{TN})$ & Both $(-)$ & Negative & Any \\
\hline
\end{tabular}


A statistical analysis was done with SPSS software ver. 22.0 (IBM, Armonk, NY, USA). Categorical variables were compared using chi-square analysis and presented as frequencies and percentages. Results were calculated as mean and standard deviation or median and range. For non-parametric data, Mann-Whitney $U$ test was used in order to compare means of two independent groups. A value of $P<0.05$ was considered statistically significant.

\section{Results}

The median age at diagnosis for patients from Kosovo and Croatia was 54 and 57 , respectively $(p=$ 0.17). The percentage of premenopausal women included in the study was $33 \%$ and $37 \%$ in Kosovo and Croatia, respectively $(p=0.97)($ Table 2$)$.

Table 2

Demographic of Kosovar and Croatian cohorts

\begin{tabular}{|llll|}
\hline & $\begin{array}{l}\text { Kosovo } \\
(\mathbf{n}=100)\end{array}$ & $\begin{array}{l}\text { Croatia } \\
(\mathbf{n}=113)\end{array}$ & p value \\
\hline $\begin{array}{l}\text { Median age } \\
(25 \%-75 \%)\end{array}$ & $54(46.25-62.00)$ & $57(46.50-57.00)$ & $p=0.17$ \\
\hline$<40$ years & $12(12 \%)$ & $11(9.7 \%)$ & $p=0.59$ \\
$\geq 40$ years & $88(88 \%)$ & $102(90.3 \%)$ & \\
\hline $\begin{array}{l}\text { Menopausal status } \\
\text { Premenopausal }\end{array}$ & $33(33 \%)$ & $37(32.7 \%)$ & $\mathrm{p}=0.97$ \\
Postmenopausal & & $76(67.3 \%)$ & \\
\hline
\end{tabular}

Share of histological types were not statistically different in the two groups. Invasive Breast Carcinoma, NST was the most common type with a frequency of about $75 \%$ in both countries. Histological grade, Ki67 proliferation index, ER status and distribution of molecular subtypes were not statistically different when compared in subjects living in Kosovo or Croatia. However, the median tumor size at diagnosis was significantly larger in subjects from Kosovo compared to Croatia $(p<0.01)$. Additionally, axillary lymph node involvement was statistically higher in Kosovar compared to Croatian patients ( $47 \%$ vs $38 \%, p=$ 0.047). The number of total and metastatic lymph nodes were also statistically higher in Kosovar patients $(p=0.02)$. The patients were staged with TNM staging system. Given that some of the sub-stage categories were empty or had small number of subjects, groups have been merged as stage I, II, and III. Among Croatian patients, $51.3 \%$ were stage I, in contrast to Kosovar patients among whom only $18 \%$ were in the same stage. There were $8.8 \%$ of stage III patients from Croatian cohort and $28 \%$ from Kosovo $(p<0.01)$. The rate of LVI was significantly higher in Kosovar patients $(p<0.01)$, as well as the expression of PR $(p=0.01)$. There were differences noticed between two cohorts regarding Her- $2 /$ neu amplification 
status but this tendency did not reach statistical significance $(p=0.07)$, (Table 3$)$. The distribution of the patients in sub-stage is presented in Table 4. 
Table 3

Comparison of tumor characteristics of Kosovar and Croatian cohort

\begin{tabular}{|c|c|c|c|}
\hline & Kosovo & Croatia & $\mathrm{p}$ value \\
\hline Histological subtype & $76(76 \%)$ & $88(78.6 \%)$ & $p=0.08$ \\
\hline IBC, NST & $6(6 \%)$ & $14(12.5 \%)$ & \\
\hline ILC & $7(7 \%)$ & $6(5.4 \%)$ & \\
\hline Mixed type & $11(11 \%)$ & $4(3.6 \%)$ & \\
\hline \multicolumn{4}{|l|}{ Other } \\
\hline $\begin{array}{l}\text { Median tumor size } \\
(25 \%-75 \%)\end{array}$ & $2.8(2.2-3.5)$ & $1.6(1.1-2.2)$ & $p<0.01$ \\
\hline Axillary involvement & $47(47 \%)$ & $38(33.6 \%)$ & $p=0.047$ \\
\hline Yes & $53(53 \%)$ & $75(66.4 \%)$ & \\
\hline \multicolumn{4}{|l|}{ No } \\
\hline $\mathrm{pN}(+)$ status & $20(42.1 \%)$ & $27(71.1 \%)$ & $p=0.02$ \\
\hline N1 & $17(36.2 \%)$ & $9(23.7 \%)$ & \\
\hline N2 & $10(21.3 \%)$ & $2(5.3 \%)$ & \\
\hline \multicolumn{4}{|l|}{ N3 } \\
\hline Stage & $18(18 \%)$ & $58(51.3 \%)$ & $p<0.01$ \\
\hline I & $54(54 \%)$ & $45(39.8 \%)$ & \\
\hline ॥ & $28(28 \%)$ & $10(8.8 \%)$ & \\
\hline \multicolumn{4}{|l|}{ III } \\
\hline Histological grade & $3(3 \%)$ & $10(8.8 \%)$ & $p=0.17$ \\
\hline G1 & $69(69 \%)$ & $69(61.1 \%)$ & \\
\hline G2 & $28(28 \%)$ & $34(30.1 \%)$ & \\
\hline \multicolumn{4}{|c|}{ G3 } \\
\hline $\begin{array}{l}\text { Ki-67 (\%) } \\
\text { (Median, 25\%-75\%) }\end{array}$ & $20(10-30)$ & $22(12-35)$ & $p=0.13$ \\
\hline Estrogen Receptor status & 77 (77\%) & $92(81.4 \%)$ & $P=0.42$ \\
\hline $\mathrm{ER}(+)$ & $23(23 \%)$ & $21(18.6 \%)$ & \\
\hline $\mathrm{ER}(-)$ & & & \\
\hline
\end{tabular}




\begin{tabular}{|llll|}
\hline & Kosovo & Croatia & P value \\
\hline ProgesteronReceptor status & $16(16 \%)$ & $45(39.8 \%)$ & $\mathrm{P}=0.01$ \\
PR(+) & $84(84 \%)$ & $68(60.2 \%)$ & \\
PR(-) & & & \\
\hline Her-2/neu amplification status & $24(24 \%)$ & $16(14.2 \%)$ & $\mathrm{p}=0.07$ \\
Her-2 (+) & $76(76 \%)$ & $97(85.8 \%)$ & \\
Her-2 (-) & & & \\
\hline LVI status & $52(52.5 \%)$ & $18(25.7 \%)$ & $\mathrm{p}<0.01$ \\
Positive & $47(47.5 \%)$ & $91(65.9 \%)$ & \\
Negative & & & $\mathrm{P}=0.01$ \\
\hline Total Lymph nodes obtained & $13(9-18)$ & $8.5(4.75-13.25)$ & \\
(Median, 25\%-75\%) & & & $\mathrm{P}<0.01$ \\
\hline Metastatic lymph nodes & $4(2-8)$ & $2(1-4.25)$ & \\
(Median, 25\%-75\%) & & & \\
\hline Molecular subtypes & $34(34 \%)$ & $43(38.1 \%)$ & \\
Lum A & $31(31 \%)$ & $44(38.9 \%)$ & \\
Lum B/HER2 neg & $12(12 \%)$ & $8(7.1 \%)$ & \\
Lum B/HER2 pos & $12(12 \%)$ & $8(7.1 \%)$ & \\
HER2 positive & $12(12 \%)$ & $18(8.8 \%)$ & \\
Triple negative & & & \\
\hline
\end{tabular}

Table 4

Breast cancer stage distribution of Kosovar and Croatian cohorts

\begin{tabular}{|c|c|c|c|c|c|c|c|}
\hline & I & $\| A$ & IIB & IIIA & IIIB & IIIC & $p<0.01$ \\
\hline Kosovo & 18 (18\%) & 37 (37\%) & $17(17 \%)$ & $18(18 \%)$ & - & $10(10 \%)$ & \\
\hline Croatia & 58 (51.3\%) & $34(30.1 \%)$ & $11(9.7 \%)$ & $8(7.1 \%)$ & - & $2(1.8 \%)$ & \\
\hline
\end{tabular}

\section{Discussion}

High-income countries are characterized by a decrease of $\mathrm{BC}$ mortality rates whereas in the developing countries incidence and mortality rates are increasing [12]. BC is most frequently diagnosed among women aged 55-64 in developed countries; median age at diagnosis is 62 in USA [13]. In this study, 
median age of the patients is 56 . This can be explained by the young age of population. The median age of Kosovar population for the year 2011 was 30.2 and for Croatian population in the year 2020 was 44.3 $[14,15]$. Cancer registry is one of the main points of cancer control. The collection of accurate data and their statistical evaluation enables sound decisions to be made in the development of national health policies. There are approximately 200 population-based registers worldwide. Through the World Health Organization (WHO), the International Research Agency (IARC) publishes global health statistics covering all countries in the world. For the use from scientific community, GLOBOCAN publishes incidence and mortality analyses on cancer every 3-5 years. The SEER (The Surveillance, Epidemiology, and End Results) program is one of the most popular register. Being affiliated with the National Cancer Institute ( $\mathrm{NCl}$ ), began collecting data as an official source of data in the US on the incidence and survival of cancer, since 1973 [16]. On the other hand the European Commission has supported the European Network of Cancer Registries (ENCR) which was established in 1990 [17].

Breast cancer screening program is an evaluation of symptom-free and otherwise healthy females for early detection of BC. Mammography is the most common BC screening modality across the world. The major merits of $\mathrm{BC}$ screening programs are early diagnosis, prevention of risk factors and timely treatment to lessen the morbidity. It also reduces the overall mortality rate by $20 \%$. The major demerits are over diagnosis, high cost, ionizing radiation, false-positive biopsy, false-negative results, and their consequences [18]. The recognition of clinical-pathological features makes it feasible to undertake the necessary preventive and treatment measures. In addition, at the time of diagnosis, BC patients in developing countries and under-developed ones, appear in more advanced stages compared to developed countries. This gap between lower and higher-income countries remains not entirely clear; nevertheless, it is attributed to racial and genetic variations, exposure to the external environment and differences in access to screening and early diagnosis methods [12]. Croatia and Kosovo have no major differences in relation to geographical coverage or lifestyle. Based on this study's findings, BC patients from Kosovo, have the median tumor size significantly larger compared to Croatian patients $(p<0.01)$. Sentinel lymph node biopsy was a widely adopted procedure in University Hospital Center Zagreb at the time this study was conducted, while in Kosovo it has not been realized at all. Only (38/113) or 33.6\% of patients from Croatia underwent axillary lymph node dissection, whereas from Kosovo (47/100) or $47 \%$. Consequently, axillary lymph node involvement was statistically higher in Kosovar compared to Croatian patients (47\% vs $33.6 \%, p=0.047)$. The number of total and metastatic lymph nodes were also statistically higher in Kosovar patients $(p=0.02)$, and therefore BC patients from Kosovo at the time of diagnosis have advanced stage in comparison to patients from Croatia, and this difference is statistically significant $(p<$ 0.01). This can be explained by the lack of application of screening and early detection methods in Kosovo. While this process has been accomplished in 2006 in Croatia, Kosovo has implemented its first mobile mammography program in 2014.

The exclusion of patients treated with neoadjuvant chemotherapy, endocrine or targeted therapy prior to surgery, is one of the reasons that patients with stage III of disease are less represented, and this is more pronounced in the Croatian cohort, due to the larger number of patients treated with neoadjuvant therapy compared to patients in Kosovo. There were differences noticed between two cohorts regarding Her- 
$2 /$ neu amplification status, respectively Kosovar cohort $24 \%$ and Croatian cohort $14.2 \%$, but this tendency did not reach statistical significance $(p=0.07)$. Her2/neu over expression as a biochemical marker for $B C$ prognosis has been proved to be linked with sentinel lymph node metastasis $[19,20,21]$.

\section{Conclusion}

The outcomes of this study show that patients with BC in Kosovo get diagnosed at a more advanced stage, when compared to $\mathrm{BC}$ patients in Croatia. Considering the geographical proximity between two countries, and the adoption of a similar life style in both countries, it may be assumed that this situation is related to the lack of community-based mammography screening, lack of education and low BC awareness in Kosovo. Based on the above, we propose organized community based screening programs in line with socio-cultural and economic structure of Kosovo population. Therefore, would highly encourage implementing screening programs to identify the disease in its early stages. Apart from information on survival of $\mathrm{BC}$ patients, better data on mortality rates are also required in order to have a more realistic view of the situation with the disease in Kosovo.

\section{Abbreviations}

BC: Breast cancer

LVl: Lympho-vascular invasion

PR: Progesteron receptor

ER: Estrogen receptor

AJCC: American Joint Committee on Cancer System

ASCO: American Society of Clinical Oncology

NST: No special type

WHO: World Health Organisation

IARC: International Research Agency

SEER: Surveilance, Epidemiology, and End Results

NCl: National Cancer Institute

ENCR: European Network of Cancer Registries

FISH: Fluorescent in situ hybridization

CISH: Chromogenic in situ hybridization 


\section{Declarations}

\section{Ethics approval and consent to participate}

The study was carried out in compliance with the Code of Ethics of the Helsinki Declaration, as well as the ethical standards of Ethics committee of the University Clinical Center of Zagreb and the University Clinical Center of Kosovo. All subjects signed an informed consent form prior to participation. Moreover, they were informed of the aim of the study, as well as of the right to withdraw and ask for their data to be destroyed.

\section{Consent for publication}

All authors have agreed to publish the paper.

\section{Competing interests}

All authors declare that they have no competing interests.

\section{Availability of the data and materials}

The datasets used and analyzed during the current study are available from the authors upon reasonable request.

\section{Conflict of Interests}

The authors declare no conflict of interests.

\section{Funding}

This study was conducted with my own funding.

\section{Authors' contributions}

The design, data analysis and previous manuscript is done by Faton Sermaxhaj. Natalija Dedić Plavetić has participate in the study design and revision of the manuscript. Ljubica Radmilović Varga, Marina Popović, Davor Mijatović and Besim Sermaxhaj participated in data collection. Statistical analyzes were performed by: Ugur Gozalan and Slavica Sović. All authors read, commented and approved the final manuscript.

\section{References}

1. Croatian Institute of Public Health, Croatian National Cancer registry, Cancer incidence in Croatia 2016, Bulletin 41, Zagreb, 2019.

2. Croatian Institute of Public Health, Croatian National Cancer registry, Cancer incidence in Croatia 2016, Bulletin 41, Zagreb, 2005. 
3. Croatian Institute of Public Health, Croatian National Cancer registry, Cancer incidence in Croatia 2016, Bulletin 41, Zagreb, 2015.

4. Croatian Institute of Public Health, Croatian National Cancer registry, Cancer incidence in Croatia 2016, Bulletin 41, Zagreb, 2012.

5. Allemani C, Matsuda T, Di Carlo V, Harewood R, Matz M, Niksic M, et al. Global surveillance of trends in cancer survival 2000-14 (CONCORD-3): analysis of individual records for 37513025 patients diagnosed with one of 18 cancers from 322 population-based registries in 71 countries. Lancet. 2018 Mar 17;391(10125):1023-1075.

6. De Angelis R, Sant M, Coleman MP, Franciski S, Baili P, Pierannunzio D, et al. Cancer survival in Europe 1999-2007 by country and age: results of EUROCARE-5-a population-based study. Lancet Oncol. 2014 Jan;15(1):23-34.

7. Kosovo Agency of Statistics-health statistics. (homepage on the internet). Prishtine (assessed: 2020 Sept 15). Available from: https://www.ask.rks-gov.net/media/5492/vjetari-final-2020-per-web.pdf

8. Goldhirsch A, Winer EP, Coates AS, Gelber RD, Piccart-Gebhart M, Thurlimann B, et al. Personalizing the treatment of women with early breast cancer: highlights of the St Gallen international expert consensus on the primary therapy of early breast cancer 2013. Ann Oncol. 2013; 24(9):2206-23.

9. Armando G, James C, Stephen E, Elizabeth M, Hope R, Lawrence S, et al. Breast Cancer-Major changes in the American Joint Committee on Cancer eighth edition cancer staging manual. CA Cancer J Clin. 2017;67(4):290-303.

10. Publication of the WHO Classification of Tumors, 5th Edition, Volume 2: Breast Tumors.

11. Hammond ME, Hayes DF, Wolff AC, Mangu PB, Temin S. American society of clinical oncology/college of American pathologists guideline recommendations for immunohistochemical testing of estrogen and progesterone receptors in breast cancer. J OncolPract. 2010;6(4):195-7.

12. Zeeshan S, Ali B, Ahmad K, Chagpar AB, Sattar AK. Clinic pathological features of young versus older patients with breast cancer at a single Pakistani institution and a comparison with a National US database. J Glob Oncol. 2019;5:1-6.

13. Desantis CE, Bray F, Ferlay J, Lortet-Tieulent J, Anderson BO, Jemal A. International variation in female breast cancer incidence and mortality rates. Cancer Epidemiol Biomarkers Prev 2015; 24:1495-1506.

14. Population of Croatia (2020 and historical). (Assessed: 2020 Sept 15). Available from: https://www.worldometers.info/world-population/croatia-population/.

15. Republic of Kosovo, Office of the Prime Minister, Kosovo Agency of statistics (homepage on the internet). Prishtine (assessed: 2020 Sept 15). Available from: https://www.ask.rksgov.net/media/5492/vjetari-final-2020-per-web.pdf.

16. Ries LG, Pollack ES, Young JL Jr. Cancer patient survival. Surveillance. Epidemiology, and End Results Program, 1973-79. J Natl Cancer Inst 1983; 70: 693-707.

17. European Commission. European network of cancer registries. Luxembourg, office for publications of the European communities, 1995. 
18. Shah TA, Guraya SS. Breast cancer screening programs: Review of merits, demerits, and recent recommendations practiced across the world. J MicroscUltrastruct. 2017;5(2):59-69.

19. Neslihan C, Sertac Y, Banu A, Kristine B, Gabriel H, Janet P, et al. CCR7 and CXCR4 as novel biomarkers predicting axillary lymph node metastasis in T1 breast cancer. Clin Cancer Res. 2005;11(16):5686-93.

20. Zhen T, Ning Sh, ZhiZh, Xiao Y, Xiao H. Expression and prognostic value of HER-2/neu in primary breast cancer with sentinel lymph node metastasis. Biosci Rep. 2017;37(4)BSR20170121.

21. Bartlett M, Ellis O, Dowsett M, Mallon A, Cameron A, Johnston S, et al. Human epidermal growth factor receptor 2 status correlates with lymph node involvement in patients with estrogen receptor (ER) negative, but with grade in those with ER-positive early-stage breast cancer suitable for cytotoxic chemotherapy. J Clin Oncol. 2007;25(28):4423-30.

22. Dimitrova, M., Lakic, D., Petrova, G., Bešlija, S., \&Culig, J. Comparative analysis of the access to health-care services and breast cancer therapy in 10 Eastern European countries. SAGE Open Medicine. (2020).

23. Erić I, Petek Erić A, Kristek J, Koprivčić I, Babić M. Breast cancer in young women: pathologic and immunohistochemical features. Acta Clin Croat. 2018;57(3):497-502.

24. Turjaka A, Berisha M, Luci L, Lulaj Sh. Breast cancer screening in Kosovo: women's knowledge and behaviours. Slovenian Journal of Public Health Volume 49:

25. Winters S, Martin C, Murphy D, Shokar NK. Breast cancer epidemiology, prevention, and screening. ProgMolBiolTransl Sci. 2017;151:1-32.

26. Duffy SW, Tabar L, Yen AM, Dean PB, Smith RA, Jonsson H, et al. Mammography screening reduces rates of advanced and fatal breast cancers: results in 549,091 women. Cancer.2020.

27. Niell BL, Freer PE, Weinfurtner RJ, Arleo EK, Drukteinis JS. Screening for breast cancer. RadiolClin North Am. 2017;55(6):1145-1162.

28. Ballard DH, Burton KR, Lakomkin N, Kim S, Rajiah P, Patel MJ, et al. The role of imaging in health screening: screening for specific conditions. AcadRadiol. 2020;1076-6332(20):30185-9.

29. Berisha M, Miftari-Basholli F, Ramadani N, Gashi S, Hoxha R, Kocinaj D. Impact of the national population register in improving health information system of malignant diseases in Kosova. Acta Inform med. 2018;26(1):62-66.

30. Shah TA, Guraya SS. Breast cancer screening programs. Review of merits, demerits, and recent recommendations practiced across the world. J MicroscUltrastruct. 2017;5(2):59-69.

31. Hrvatskizavodzajavnozdrvastvo(homepage on the internet). Zagreb (accessed:2019 Oct 11) Available from: https://www.hzjz.hr/aktualnosti/nacionalni-program-ranog-otkrivanja-raka-dojke.

32. Hrvatskizavodzajavnozdrvastvo(homepage on the internet). Zagreb (accessed:2019 Oct 11) Available from: https://www.hzjz.hr/sluzba-epidemiologija-prevencija-nezaraznih-bolesti/obiljezendan-narcisa-2019/. 